\title{
Effect on The Decrease Intensity Gymnastics Rheumatic Pain in Patients Gout Arthritis
}

\author{
Fira Dewi Cahyani ${ }^{1)}$, Fajar Surachmi ${ }^{1)}$, Sri Eny Setyowati ${ }^{1)}$ \\ 1) Department of Nursing, Semarang Health Polytechnic \\ Corresponding author: firawicak@gmail.com
}

\begin{abstract}
Background: One of complaints caused by gout arthritis one of which is joint pain. Deposition of urate crystals in joints and tendons to continue and cause damage that will restrict the movement of the joint. Gouty arthritis is characterized by the accumulation of monosodium urate crystals in or around the joints. Monosodium urate crystals activates osteoblasts to secrete cytokines and lower the anabolic functions that will contribute to the destruction juxta-articular bone. Therefore, it is necessary interventions are triggered reduction in pain intensity exercise rheumatism.

Purpose: Knowing the influence of gymnastics rheumatism to changes in the intensity of pain in patients with arthritis in the Gunungpati Health Center Working Area.

Methods: This study uses a Pre-Experimental one group pre and post-test without control group design. The research sample of 15 people with gout arthritis in Puskesmas Gunungpati Semarang on 1 to 7 April 2019. The sampling technique with purposive sampling and analysis of data processing with the Wilcoxon test.

Results: The results showed a pain scale before treatment equal to $4.67 \pm 0724$ and the scale of pain after treatment decreased to $0.60 \pm 0.507$. The results of the analysis using the Wilcoxon test shows the $\mathrm{p}$ value 0.000 which proves that there is a significant difference between before and after treatment of arthritis exercises to decrease pain scale in patients with gout arthritis.

Conclusion: In this study indicate that there is influence of the reduction scale gymnastics rheumatic pain in gouty arthritis patients in Puskesmas Gunungpati Semarang.
\end{abstract}

\section{Keywords:}

Arthritis Gout; Gymnastics Rheumatism; Pain Scale

\section{LATAR BELAKANG}

Dewasa ini terjadi peningkatan angka kejadian penyakit tidak menular (PTM) atau disebut juga penyakit degeneratif. Disebut penyakit degeneratif karena angka kejadiannya bersangkutan dengan proses degenerasi pada usia lanjut yang berlangsung sesuai waktu dan umur (Irianto, 2014). Salah satu diantaranya adalah nyeri sendi, salah satu penyebab nyeri sendi yaitu nyeri sendi yang disebabkan oleh tingginya kadar purin dalam tubuh (hiperurisemia) atau sering disebut asam urat. Asam urat disebut juga artritis gout termasuk suatu penyakit degeneratif yang menyerang persendian, dan paling sering dijumpai di masyarakat terutama dialami oleh lanjut usia (lansia). Namun tak jarang penyakit ini juga ditemukan pada golongan pralansia (Damayanti, 2012). 
Pada orang dewasa di Amerika Serikat penyakit gout mengalami peningkatan dan mempengaruhi 8.3 juta (4\%) orang Amerika. Sedangkan prevalensi hiperurisemia juga meningkat dan mempengaruhi 43.300 .000 (21\%) orang dewasa di Amerika Serikat (Zhu dkk, 2011 dalam Sun, 2014).

Menurut World Health Organisation (WHO) tahun 2016, 335 juta penduduk di dunia yang mengalami Arthritis. Prevalensi penyakit Gout Arthritis yaitu 0,5\%-1\% dari sebuah populasi. Secara geografis, persebaran penyakit Gout Arthritis tidak merata dan banyak dialami oleh jenis kelamin perempuan. Rentang umur yang sering mengalami biasanya usia 45-65 tahun.

Menurut RISKESDAS 2018, angka kejadian penyakit sendi mencapai 11,9\% dari total penduduk di Indonesia. Hasil Riskesdas 2018, Provinsi Jateng mengalami peningkatan angka kejadian nyeri sendi di usia $\geq 15$ tahun yaitu $7,2 \%$ dari total populasi penduduk Jawa Tengah. Namun, dari suatu survei epidemiologik yang dilakukan di Jawa Tengah atas kerjasama WHO terhadap 4683 sampel berusia 15-45 tahun, didapatkan prevalensi artritis gout sebesar 24,3\% (Nengsi dkk, 2014).

Penyakit asam urat diperkirakan terjadi pada 840 orang dari setiap 100.000 orang. Pada suatu studi didapatkan insidensi gout athritis $4,9 \%$ pada kadar asam urat darah $>9$ $\mathrm{mg} / \mathrm{dL}, 0,5 \%$ pada kadar 7-8,9 mg/dL, dan 0,1\% pada kadar $9 \mathrm{mg} / \mathrm{dL}$ (Hidayat, 2009).

Dari studi pendahuluan yang telah dilakukan pada tanggal 19 Oktober 2018 di Puskesmas Gunungpati Kota Semarang didapatkan data jumlah penderita asam urat mulai dari bulan Januari hingga bulan Oktober 2018 terdaftar sebanyak 63 kasus Arthritis di Puskesmas Gunungpati. Sebagian besar usia penderita Arthritis 45-59 tahun. Menurut Depkes RI tahun 2013 usia tersebut termasuk dalam kategori pra lansia.

Penatalaksanaan nyeri sendi dapat diberikan terapi farmakologis dan terapi non farmakologis. Kolaborasi dalam pemberian terapi farmakologis dan non farmakologis dapat mengurangi nyeri sendi lebih optimal. Hasil dari beberapa penelitian membuktikan bahwa nyeri sendi dapat dikurangi dengan menggunakan terapi non farmakologis salah satunya yaitu senam rematik.

Pada dasarnya gerakan-gerakan senam rematik berguna untuk meningkatkan kemampuan gerak, fungsi kekuatan dan daya tahan otot, kapasitas aerobic, keseimbangan, biomekanika, sendi dan tulang sendi ((Siti, 2008) dikutip dalam kompas). Secara umum, gerakan-gerakan senam rematik adalah latihan pernafasan, latihan persendian, latihan kekuatan, latihan jantung, latihan peregangan yang dimaksudkan untuk meningkatkan kemampuan gerak, fungsi, kekuatan, dan daya tahan otot, kapasitas aerobic, keseimbangan, biomekanik sendi, dan 3 rasa posisi sendi. Untuk mencapai hasil yang maksimal, senam rematik baiknya dilakukan tiga sampai lima kali dalam seminggu (Annisa, 2011).

Penelitian yang dilakukan oleh Meliana Sitinjak (2016) yang meneliti tentang pengaruh senam rematik terhadap pengurangan intensitas nyeri di Panti Werdha Sinar Abadi Singkawang, diperoleh hasil analisis nilai p-value sebesar 0,000 pada kelompok 
perlakuan dan kelompok kontrol p-value sebesar 0,017 ( $\mathrm{p}<0,05)$. Hal ini berarti terdapat perbedaan skala nyeri sendi antara kelompok perlakuan yang diberikan intervensi senam rematik dan kelompok kontrol yang tidak diberikan senam rematik, dimana skala nyeri sendi dengan senam rematik lebih rendah daripada skala nyeri yang tidak diberikan senam rematik.

Berdasarkan data-data di atas dapat disimpulkan bahwa keluhan yang ditimbulkan oleh penyakit arthritis salah satunya yaitu nyeri sendi. Nyeri sendi yaitu melemahnya tulang rawan pada engsel yang dapat terjadi di engsel maupun seluruh tubuh (Murwani, 2010).

\section{TUJUAN}

Untuk mengetahui pengaruh senam rematik terhadap perubahan intensitas nyeri terhadap penderita Arthritis di wilayah kerja Puskesmas Gunungpati.

\section{METODE}

Penelitian ini menggunakan Pra Eksperimen dengan rancangan One group pre and posttest design. Peneliti telah melakukan penelitian pada satu kelompok sampel yaitu penderita gout arthritis dengan intensitas nyeri yang <6 untuk dilakukan intervensi berupa senam rematik. Sampel penelitian ini dinilai skala nyerinya menggunakan lembar observasi nyeri (NRS) terlebih dahulu (pre test) kemudian diberikan perlakuan berupa senam rematik. Setelah diberikan perlakuan, peneliti menilai kembali skala nyeri dari sampel tersebut (post test). Kemudian dianalisa untuk mengetahui pengaruh dari penelitian yang telah dilakukan.

\section{HASIL}

Karakteristik responden $(n=15)$ berdasarkan jenis kelamin adalah seluruhnya berjenis kelamin perempuan $(100 \%)$.

Tabel 1 Karakteristik Responden ( $\mathrm{n}=15)$ Berdasarkan Pekerjaan

\begin{tabular}{lcc}
\hline \multicolumn{1}{c}{ Pekerjaan } & Frekuensi & Presentase (\%) \\
\hline Buruh/Petani & 3 & 20 \\
Wiraswasta & 1 & 6.7 \\
Pegawai & 1 & 6.7 \\
Ibu Rumah Tangga & 8 & 53.3 \\
Tidak Bekerja & 2 & 13.3 \\
Total & 15 & 100 \\
\hline
\end{tabular}

Berdasarkan Tabel 1 didapatkan hasil bahwa responden terbanyak berprofesi sebagai Ibu Rumah Tangga yaitu sebanyak 8 responden (53.3\%). 
Tabel 2 Gambaran skala nyeri sebelum dan sesudah dilakukan senam rematik $(n=15)$

\begin{tabular}{lcccc}
\hline \multirow{2}{*}{ Skala Nyeri } & \multicolumn{2}{c}{ Sebelum } & \multicolumn{2}{c}{ Sesudah } \\
\cline { 2 - 5 } & $\mathrm{f}$ & $\%$ & F & $\%$ \\
\hline Tidak Nyeri & - & - & 6 & 40,0 \\
Nyeri Ringan & - & - & 9 & 60,0 \\
Nyeri Sedang & 15 & 100 & - & - \\
\hline
\end{tabular}

Berdasarkan Tabel 2 di atas menggambarkan skala nyeri sebelum dilakukan senam rematik didapatkan hasil yaitu keseluruhan responden mengalami nyeri sedang $(100,0 \%)$. Sedangkan, skala nyeri sesudah dilakukan senam rematik didapatkan hasil yaitu mengalami penurunan menjadi nyeri ringan sebanyak 9 responden $(60,0 \%)$.

Tabel.3 Hasil Wilcoxon perubahan skala nyeri pada penderita gout artritis sebelum dan sesudah dilakukan senam rematik

\begin{tabular}{ccc}
\hline Skala Nyeri & Mean \pm SD & p value \\
\hline Sebelum & $4.67 \pm 0.724$ & $<0.001$ \\
Sesudah & $0.60 \pm 0.507$ & \\
\hline
\end{tabular}

Berdasarkan Tabel 3 hasil uji Wilcoxon pada perbedaan skala nyeri pada penderita gout arthritis sebelum dan sesudah dilakukan senam rematik didapatkan hasil $p$ value 0.000 sehingga $p$ value $<0.05$. apabila $\mathrm{p}$ value $<0.05$ maka Ha diterima, artinya ada perbedaan skala nyeri sebelum dan sesudah dilakukan senam rematik. Jadi dapat disimpulkan bahwa ada pengaruh senam rematik terhadap penurunan skala nyeri pada penderita gout arthritis. Selisih minimum penurunan skala nyeri yaitu 4,07.

\section{PEMBAHASAN}

Berdasarkan analisis data menunjukkan bahwa karakteristik jenis kelamin semuanya adalah responden perempuan yaitu 15 responden (100,0\%). Hasil tersebut sesuai dengan penelitian Sriwiyati dan Noviyanti (2018) yang menyatakan bahwa responden yang menderita asam urat sebanyak $94.9 \%$ berjenis kelamin perempuan. Wanita mengalami peningkatan resiko asam urat setelah menopause, resiko mulai meningkat pada usia 45 tahun ke atas akibat penurunan level estrogen, karena estrogen memiliki efek urikosurik/diuretik. Dalam hal ini dapat mencegah terjadinya penumpukan kadar asam urat di dalam tubuh pada perempuan karena asam urat larut saat urin diekskresikan. Menurut Smeltzer and Bare (2008) jenis kelamin mempunyai pengaruh penting dalam berespon terhadap nyeri. Perbedaan jenis kelamin telah diindentifikasi dalam hal nyeri dan respon nyeri.

Wanita memiliki sensitifitas yang tinggi dalam merespon rasa nyeri. Wanita juga lebih beresiko mengalami peningkatan kadar asam urat saat mengalami menopause. 
Pada penelitian ini mayoritas perempuan yang mengalami peningkatan asam urat adalah perempuan yang berusia lebih dari 50 tahun, sehingga tingginya asam urat pada responden perempuan tersebut dapat disebabkan karena penurunan level estrogen akibat menopause ataupun karena faktor usia. Pengaruh estrogen pada kadar asam urat di dalam darah dikaitkan dengan ekskresi asamurat melalui ginjal. Ekskresi asam urat pada wanita yang masih memproduksi estrogen dapat normal, namun pada wanita yang sudah tidak memproduksi estrogen, ekskresi asam urat tidak terbantu dan dapat menimbulkan hiperurisemia. Estrogen meningkatkan ekskresi asm urat ginjal, spesifiknya estrogen jenis estradiol yang menekan tingkat protein dari URATI dan Glut9 sehingga meningkatkan ekskresi asam urat dari darah melalui ginjal sehingga tidak terjadi hiperurisemia (Moriwaki,2014).

Berdasarkan usia pada penelitian ini menggunakan batasan usia responden yang menderita asam urat berusia yaitu 45-59 tahun. Hasil penelitian yang dilakukan Hastuti, dkk (2018) rentang usia yang beresiko terkena gout artritis adalah usia $>40$ tahun, karena diketahui sistem metabolisme pada usia tersebut sudah mulai terganggu atau mengalami penurunan fungsi, namun tidak menutup kemungkinan kelompok usia produktif juga dapat terkena.

Pada klien dengan gout arthritis di usia pra lansia kemungkinan mengalami pengeroposan tulang, sehingga dapat menambah rasa nyeri yang dirasakan oleh klien terutama pada cuaca dingin dan pagi hari, hal ini diakibatkan karena kerusakan jaringan sendi, kerusakan tulang rawan (kartilago) sendi dan tulang didekatnya, disertai perforasi dari tulang dan jaringan lunak didalam dan sekitar daerah yang terkena. Pada umumnya pra lansia dengan artritis rheumatoid mengalami nyeri dengan intensitas nyeri sedang (4-6). Nyeri tersebut sering dirasakan oleh klien pada daerah lutut, kaki, pergelangan kaki dan tangan, dan di berbagai persendian lainya. Rata-rata klien merasa terganggu dalam beraktivitas karena rasa nyeri yang dialaminya. Jika nyeri tidak diatasi dengan segera, ini akan berlanjut hingga nyeri berat dan dapat mengganggu aktivitas klien. Menurut Ode (2012) usia merupakan faktor resiko tingginya kadar asam urat dalam tubuh, karena ketika seseorang bertambah tua maka akan terjadi perubahan berupa penurunan proses metabolisme dalam tubuh.

\section{Tingkat skala nyeri penderita gout artritis sebelum diberikan senam rematik}

Hasil penelitian yang dilakukan di wilayah Kerja Puskesmas Gunungpati Semarang terhadap 15 responden, didapatkan frekuensi skor tingkat skala nyeri sebelum diberikan perlakuan yaitu sebanyak 15 responden $(100.0 \%)$ memiliki tingkat nyeri sedang.

Menurut Afroh, dkk (2012) nyeri sebagai pengalaman yang tidak menyenangkan, baik sensori maupun emosional yang berhubungan dengan resiko atau aktulnya kerusakan jaringan tubuh. Nyeri sangat berpengaruh pada saat terjadi penumpukkan Kristal asam urat yang ditandai dengan kekakuan pada satu atau lebih pada sendi terjadi di pergelangan tangan, kaki, lutut, panggul dan bahu. Merasakan nyeri pada lanjut usia dapat mengganggu pola aktivitas sehari-hari. Hal ini dapat terjadi karena banyaknya faktor yang dapat mempengaruhi diantaranya budaya, persepsi seseorang, perhatian dan variable-variable psikologis lain yang mengganggu perilaku berkelanjutan. 
Pada penelitian ini budaya yang terjadi adalah adanya budaya bercocok tanam dengan hasil panen berupa bayam, kacang-kacangan, nangka, dan durian, dimana bahan-bahan tersebut mengandung kadar purin yang tinggi dan sering dikonsumsi oleh masyarakat dalam kehidupan sehari-hari. Kebiasaan minum air putih di kalangan pra lansia kurang menjadi prioritas oleh pra lansia itu sendiri. Hal ini didukung oleh Diantri dan Chandra (2013) meningkatnya kadar asam urat dipengaruhi oleh asupan makanan tinggi purin. Sementara, konsumsi cairan yang tinggi dapat menurunkan kadar asam urat, karena cairan berfungsi sebagai pelarut dan sebagai media pembuangan hasil metabolisme.

Disamping itu, responden pada penelitian ini mayoritas sebagai ibu rumah tangga (tanpa asisten rumah tangga) sehingga intensitas aktivitas yang dilakukan sedang hingga berat dan tanpa diawali dengan peregangan otot pada saat akan memulai aktivitasnya. Hal tersebut didukung oleh teori Ilyas (2014) yang menyebutkan bahwa aktivitas fisik menjadi penyebab yang dapat meningkatkan kadar asam urat darah karena produksi asam laktat selama beraktifitas terutama aktifitas fisik yang berat. Hasil penelitian oleh Dayana (2015) ditemukan terdapat hubungan bermakna antara kategori intensitas aktivitas fisik dan kadar asam urat. Hal tersebut mengindikasikan bahwa intensitas aktivitas fisik sedang sampai tinggi memberikan risiko terhadap angka kejadian kadar asam urat tinggi.

Nyeri ini dikarenakan terjadinya peradangan dari proses imunitas oleh leukosit yang melawan kristal asam urat sehingga terjadi peningkatan sirkulasi darah pada daerah radang yang memicu vasodilatasi pada pembuluh darah kapiler, maka menyebabkan nyeri (adanya eritema dan panas) (Price, 2006).

\section{Tingkat skala nyeri penderita gout artritis sesudah diberikan senam rematik}

Tingkat skala nyeri setelah dilakukan senam rematik yaitu sebanyak 6 responden (40.0\%) dengan tidak nyeri dan sebanyak 9 responden $(60.0 \%)$ dengan nyeri ringan.

Kelebihan dari senam rematik tidak hanya pada gerakan yang aktif, berulang, dan mudah dilakukan. Sesudah melakukan gerakan senam rematik lansia terlihat rileks, nyaman, dan menunjukkan ekspresi wajah tersenyum. Menurut penelitian Bender et al., (2007), latihan atau senam dalam hal ini termasuk senam rematik memiliki dampak psikologis langsung yakni membantu memberi perasaan santai, mengurangi ketegangan, dan meningkatkan perasaan senang karena saat senam kelenjar pituitari menambah produksi atau meningkatkan level betaendorfin. Peningkatan konsentrasi beta-endorfin di dalam darah dan saraf parasimpatis menurunkan denyut jantung dan denyut nadi sehingga menyebabkan nyeri yang memunculkan kekakuan sendi berkurang. Hal ini didukung oleh Nursalam dan Kurniawati (2013), selain produksi beta-endorfin, senam juga meningkatkan aktivitas penyaluran saraf didalam otak yaitu peningkatan neurotransmitter parasimpatis (norepinephrine, dopamine, dan serotonin).

\section{Pengaruh Terapi Senam Rematik Terhadap Penurunan Skala Nyeri pada Penderita Gout Artritis}

Hasil penelitian menunjukkan nilai mean sebelum dilakukan dilakukan senam rematik adalah 4.67 dengan standar deviasi 0.724 dan nilai mean setelah dilakukan senam 
rematik adalah 0.60 dengan standar deviasi 0.507. Sedangkan dengan menggunakan uji Wilcoxon menunjukkan bahwa nilai p value $<0.001$.

Latihan senam rematik yang teratur merupakan salah satu upaya menjaga kebugaran dan kesehatan tubuh klien. Menurut penelitian Bender et al., (2010), terapi fisik mampu meningkatkan level beta-endorfin di dalam tubuh. Dengan beristirahat hanya mampu menurunkan skala nyeri dengan rentang penurunan yang kecil karena istirahat seperti tidur atau duduk diam tanpa pergerakan tidak merangsang pelepasan endorfin. Pergerakan seperti senam rematik dan olahraga memiliki dampak yang lebih baik bagi penderita nyeri sendi dibandingkan dengan beristirahat atau duduk diam.

Menurut the gate control theory (teori kontrol pintu), upaya menutup pertahanan untuk mencegah pelepasan substansi $\mathrm{C}$ dan substansi $\mathrm{P}$ yang merupakan pentransmisi nyeri adalah dengan menghasilkan masukan dominan serabut beta-A yang akan menghambat nyeri, upaya ini dapat dilakukan salah satunya dengan latihan fisik (Muttaqin, 2008). Menurut Hunter \& Felix (2010), latihan fisik dapat meningkatkan sirkulasi darah dan merangsang peningkatan enzim-enzim tubuh yang berperan dalam proses oksigenasi jaringan. Nyeri sendi pada penderita Gout Arthritis termasuk dalam kategori nyeri somatik dalam dimana reseptor nyeri ini terletak pada otot dan tulang serta penyokong tubuh lainnya. Tubuh memiliki neuromodulator alami yang dapat menghambat transmisi impuls nyeri salah satunya adalah beta-endorfin. Menurut American Geriatric Society olahraga seperti senam minimal tiga kali seminggu secara signifikan dapat memperbaiki kesehatan pasien pasien arthritis termasuk Gout Arthritis.

Olahraga senam dapat menstimulasi peningkatan pelepasan hormon endorfin. Endorfin memberikan efek analgesia dengan memblokir proses pelepasan substansi $\mathrm{p}$ dari neuron sensorik sehingga proses transmisi impuls nyeri di medula spinalis menjadi terhambat dan sensasi nyeri menjadi berkurang. Nyeri yang dirasakan pada saat melakukan aktivitas sehari-hari, pembengkakan pada sendi, kaku sendi, kelelahan, bahkan kelainan bentuk tubuh sering dialami orang yang menderita arthritis, fokus penanganan penderita Arthritis adalah mengontrol rasa nyeri, mengurangi kerusakan sendi, serta mempertahankan fungsi kualitas gerak. Pada orang yang normal gerakan menjadi terjaga karena dapat bergerak aktif. Kapasitas konsentrasi senam rematik terletak pada gerakan sendi yang meregangkan dan menguatkan otot, karena otot-otot tersebut yang membantu sendi untuk menopang tubuh.

Senam yang diberikan kepada responden tidak perlu terlalu berat, cukup dengan gerakan pelan dan dapat diikuti oleh responden serta mengandung unsur pemanasan dan pendinginan. Di dalam senam rematik untuk lansia sudah mengandung unsur yang melibatkan kontraksi otot yang dinamis dan melibatkan banyak otot yang dapat meningkatkan volume curah jantung. Senam rematik memiliki 6 tahapan yaitu latihan pernapasan, latihan kekuatan, latihan pemanasan, latihan persendian, latihan kardio, dan peregangan. Menurut penelitian Bender et al., (2007), latihan atau senam dalam hal ini termasuk senam rematik memiliki dampak psikologis langsung yakni membantu memberi perasaan santai, mengurangi ketegangan, dan meningkatkan perasaan senang karena saat senam kelenjar pituitari menambah produksi atau meningkatkan level betaendorfin. Hal ini didukung oleh Nursalam dan Kurniawati (2014), selain produksi beta- 
endorfin, senam juga meningkatkan aktivitas penyaluran saraf didalam otak yaitu peningkatan neurotransmitter parasimpatis (norepinephrine, dopamine, dan serotonin). Peningkatan konsentrasi beta-endorfindi dalam darah dan saraf parasimpatis menurunkan denyut jantung dan denyut nadi sehingga menyebabkan nyeri yang memunculkan kekakuan sendi berkurang.

Hasil penelitian ini konsisten dengan penelitian Sangrah (2018) yang menunjukkan bahwa ada pengaruh yang signifikan dari pemberian perlakuan yang berupa pemberian senam rematik terhadap penurunan skala nyeri pada Gout Artritis dengan mean pre test sebesar 7.00 dan post test sebesar 4.50.

\section{SIMPULAN}

Seluruhnya intensitas skala nyeri sebelum dilakukan senam rematik pada penderita gout arthritis adalah sebesar 4,67 yaitu dengan nyeri sedang sebanyak 15 orang (100\%).

Rata-rata intensitas skala nyeri sesudah dilakukan senam rematik pada penderita gout arthritis adalah 0,60 yaitu dengan nyeri ringan sebanyak 9 orang $(60 \%)$ dan tidak nyeri sebanyak 6 orang $(40 \%)$.

Ada pengaruh senam rematik terhadap penurunan intensitas skala nyeri pada penderita gout arthritis ( $\mathrm{p}$ value $\leq 0.001$ ). Dengan selisih skala nyeri sebelum dan sesudah dilakukan senam rematik yaitu sebesar 4,07.

\section{REFERENSI}

Afroh F, Judha M, Sudarti. (2012). Teori pengukuran nyeri \& nyeri persalinan. Yogyakarta: Nuha Medika.

Annisa, Siti. (2011). Kekuatan otot dan mobilitas usia lanjut setelah latihan penguatan isotonik. Jurnal of Gerontology Vol.61 No.1.

Bender, T., et al. (2010). The effect of physical therapy on beta-endorphin levels. European Journal Of Applied Physiology, 100(4), p.371-382. Diakses pada $\begin{array}{llll}\text { tanggal } & 26 & \text { April }\end{array}$ https://scholar.google.com/citations?user=6x5nfAoAAAAJ\&hl=en

Damayanti, D. (2012). Mencegah dan mengobati asam urat. Bantul: Rapha Publishing.

Dayana B, Udin B. (2015). Hubungan antara intensitas aktivitas fisik dan kadar asam urat serum pada populasi sindrom metabolik. Diakses pada tanggal 26 April 2019. https://media.neliti.com/media/publications/139030-ID-none.pdf

Diantri dan Chandra, (2013). Pengaruh asupan purin dan cairan terhadap kadar asam urat pada wanita usia 50-60 tahun di kecamatan gajah mugkur semarang. Journal Of Nutrition College. Vol. 2, No. 1, Hal. 44-49. Diakses pada tanggal 25 April 2019. http://e-journal-s1.undip.ac.id/index .php/jnc

Hastuti, dkk. (2018). Hubungan Asupan Protein Total dan Protein Kedelai Terhadap Kadar Asam Urat Dalam Darah Wanita Menopause. Journal of Nutrition College. Vol. 7, No. 2, Hal. 57-59. Diakses pada tanggal 25 April 2019. http://ejournal3.undip.ac.id/index.php/jnc/

Hidayat, R. (2009). Gout dan hiperurisemia. Divisi Reumatologi Departemen Ilmu Penyakit Dalam Fakultas Kedokteran Universitas Indonesia, Jakarta. 
Ilyas, N. O., Suprihartono, F. A., \& Dewi, M. (2014). Beberapa Faktor yang Berhubungan dengan Kejadian Hiperurisemia pada Pasien Rawat Jalan di RS Dustira Cimahi. Jurnal gizi indonesia. Vol. 2, No. 37, Hal. 91-100. Diakses pada tanggal $25 \quad$ April 2019. https://www.ejournal.persagi.org/index.php/Gizi_Indon/article/view/154

Irianto K. (2014). Epidemiologi penyakit menular dan tidak menular panduan klinis. Bandung: Alfabeta.

Meliana Sitinjak, Vivi \& Hastuti, Maria \& Nurfianti, Arina. (2016). Pengaruh senam rematik terhadap perubahan skala nyeri pada lanjut usia dengan osteoarthritis lutut. Jurnal Keperawatan Padjadjaran. Vol. 4, No. 2, Hal 139-150. Diakses $\begin{array}{llll}\text { pada } & \text { tanggal } & 20 & \text { April }\end{array}$ http://jkp.fkep.unpad.ac.id/index.php/jkp/article/view/234/126

Moriwaki, Y. (2014). Effects on Urid Acid Metabolism of the Drugs except the Anthiperuricemics. Journal of Bioquivalence \& bioavailability. Vol. 6, No..1 Hal. 10-14 Diakses: 25 Maret 2019. http://www.ejournal.stikesmucis.ac.id

Nengsi, S. W. dkk, (2014). Gambaran asupan purin, penyakit artritis gout, kualitas hidup lanjut usia di kecamatan tamalanrea. Hal 4-5. Diakses pada tanggal 27 April 2019. www.adln.lib.unhas.ac.id.go

Nursalam dan Kurniawati, Ninuk D. (2013). Asuhan Keperawatan pada Pasien Terinfeksi HIV/AIDS. Jakarta: Salemba Medika

Nursalam, (2008). Konsep dan penerapan metodologi penelitian ilmu keperawatan. Jakarta: Salemba Medika

Ode, Sarif. (2012). Asuhan keperawatan gerontik. Yogyakarta: Nuha Medika.

Riset Kesehatan Dasar(Riskesdas). (2018). Badan Penelitian dan Pengembangan Kesehatan Kementerian RI tahun 2018. Diakses: 19 Oktober 2018, dari http://www.depkes.go.id/resources/download/general/Hasil\%20Riskesdas\%20 2018.pdf.

Sangrah, Muh Wahid. (2017). Pengaruh Senam Rematik terhadap Penurunan Nyeri dan Peningkatan Rentang Gerak Osteoatritis Lutut Lansia. Diakses pada tanggal 30 April 2019. http://repositori.uin-alauddin.ac.id

Smeltzer, S, \& Bare. (2008). Brunner \& Suddarths Textbook of Medical Surgical Nursing. Philadelpia: Lippin cott

World Health Organization. (2015). Noncom- municable diseases. (Online), (http://www.who.int/ mediacentre/factsheets/fs355/e/. Diakses 20 November 2018).

2019. http://juke.kedokteran.unila.ac.id/index.php/medula/article/view/115/113

Zhu, Y. , Pandya, B. J. and Choi, H. K. (2011). Prevalence of gout and hyperuricemia in the US general population: The National Health and Nutrition Examination Survey 2007-2008. Arthritis \& Rheumatism. American College of Rheumatology. Vol. 63, No.10, Hal. 3136-3141. Diakses pada tanggal 20 April 2019. doi: $10.1002 / \operatorname{art} .30520$ 